\title{
Subsidizing National Champions: An Evolutionary Perspective
}

\author{
CÉCILE AUBERT \\ OLIVER FALCK \\ STEPHAN HEBLICH
}

CESIFO WORKING PAPER NO. 2380

CATEGORY 9: INDUSTRIAL ORGANISATION

August 2008

\footnotetext{
An electronic version of the paper may be downloaded

- from the SSRN website: Www.SSRN.com

- from the RePEc website: Www.RePEc.org

- from the CESifo website: www.CESifo-group.org/wp
} 


\title{
Subsidizing National Champions: An Evolutionary Perspective
}

\begin{abstract}
A national-champions-related industrial policy has become (again) en vogue among European politicians. Against this background, our work orders different types of national champions along the industry lifecycle. Different types of locally bound externalities appear along the lifecycle. In a simple model, we show that it may be efficient to subsidize innovative firms in their early stages or to protect mature firms from competition to appropriate these externalities. However, non-benevolent politicians may not choose efficient policies. Realworld examples indicate that politicians tend to concentrate on externalities at the mature stage of the lifecycle. These externalities may be transitory or at the expense of foreign country consumers.
\end{abstract}

JEL Code: L52, O25, O33, P11.

Keywords: national champions, industrial policy, industry lifecycle, externalities.

Cécile Aubert

University of Bordeaux IV

(GREThA) and Toulouse School of

Economics (TSE LERNA)

21 allée de Brienne

France - 31 042, Toulouse Cedex

Cecile.Aubert@u-bordeaux4.fr
Oliver Falck

Ifo Institute for Economic Research

at the University of Munich

Poschingerstrasse 5

81679 Munich

Germany

falck@ifo.de

\author{
Stephan Heblich \\ Max Planck Institute of Economics \\ Entrepreneurship, Growth, and Public Policy Group \\ Kahlaischestrasse 10 \\ 07745 Jena \\ Germany \\ heblich@econ.mpg.de
}

31 July 2008

An earlier version of this paper was presented at the CESifo conference "Do We Need National or European Champions?” in Munich, 16-17 November 2007. This workshop was funded by the German Leibniz Association within the project "How to construct Europe". We are grateful for insightful comments and suggestions by Paul Seabright and other workshop participants, as well as by an anonymous referee. 


\section{Introduction}

One central element of the EU's Lisbon Strategy is to make Europe "the most competitive and dynamic knowledge-based economic region in the world" by 2010 . Although there are many different ways to reach this goal, the idea of an industrial policy that promotes European or national champions as the best way to compete in a globalized world has become (again) en vogue among European politicians.

While the desirability of promoting champions is the object of much discussion, it is not always clear what a champion is, nor what type of champion will receive the most attention from politicians (Maincent and Navarro 2006). In a rapidly changing business environment, national champions can be up and coming firms engaged in creative destruction, innovative firms operating at or close to the technology frontier, or large firms that serve to confer prestige on the politicians who support and protect them. In this chapter, we argue that these different types of champions occur at different phases of a product lifecycle. According to Gort and Klepper's (1982) knowledge-based view, the phases along a product lifecycle are defined as follows. The very "early" phase is best characterized by experimentation undertaken in the quest for a dominant product variant - leading to high firm turnover. In the "intermediate" phase, some product variants dominate the growing market - leading to firm growth and firm entry but very little exit. In the "mature" phase, firms concentrate on process innovations so as to reduce production costs and there will be a certain amount of market entry by new firms that do very little of their own research but, instead, simply copy the now established product and benefit from low production costs (e.g., a low-paid workforce). Once confronted by competition from these low-cost firms, national firms must keep pace 
with the speed of process innovation, develop new products along another lifecycle, or exit the market (see also Klepper, 1996, 1997). We argue that different knowledge externalities are generated in each stage, and that these may warrant government intervention, to foster investment and efficient redeployment of assets. While this theoretical result holds for a benevolent government, examples of costly policies by politicians concerned with reelection are also discussed.

\section{Competitive pressure and innovation}

According to Aghion et al. (2008), for firms at the technology frontier, constant innovation is the only way to escape competition, either from new entrants or existing firms. Competition should thus provide a disciplining effect on firms, and lead to innovation. However, firm failure only occurs in competitive markets. If a firm feels fairly confident that the government will protect and support it, no matter what its position in the market, the firm will most likely not spend much time, money, or effort on innovation. This innovation-inhibiting situation is even more likely to manifest when the politicians supporting the firm are up for reelection (Dewatripont and Seabright, 2006), as voters are uncomfortable with an economy founded on unpredictable firm selection (leading to fast but erratic growth) and prefer slow but smooth growth (Roe, 2003). In consequence, politicians seeking reelection will prefer to subsidize those firms or industries that are in danger of becoming losers in a process of creative destruction. Because firms are very well aware of this, their incentive to invest in research, to innovate, and to relocate their assets in more profitable activities is reduced. 


\section{Promoting national champions under externalities}

In this chapter, we focus on industries where firms need to innovate and develop new products to survive. Despite the adverse effect just described, there may still be a rationale for a benevolent politician to intervene at some stage of the lifecycle. Several market imperfections may justify intervention. First, competition is unlikely to lead to efficient levels of innovation and of redeployment of assets in the presence of externalities and information leakages. We will argue that such externalities are important in the industries we consider. Second, competition may also not lead to efficiency in the presence of imperfect credit markets. Therefore, we consider two types of intervention that may improve overall efficiency, namely subsidizing innovative firms in their early stages, and protecting mature ones from competition. We compare the impact of these two ways of promoting national champions under the assumption of a benevolent politician. In doing so, we consider the case in which both forms of intervention reinforce the incentive of local firms to invest in R\&D activity. This will be particularly beneficial when such investments generate positive local externalities, including, for example, tacit knowledge acquired by firms and employees and/or processes adopted from other industries (such spillovers are commonly assumed in the endogenous growth literature). Some form of intervention is also beneficial when competitors may copy a new good or technology without bearing R\&D costs - thus expropriating, to some extent, the research efforts of innovators. However, as we will argue, the investments undertaken due to government intervention may not be adequate.

The existing champions-related literature concentrates on the distribution of rents. Not surprisingly, a large part of this literature finds its foundation in the strategic trade 
policy literature. In this latter strand of research, markets are characterized by worldwide imperfect competition and suppliers from around the world compete to capture excess rents. To retain the largest possible share of these excess rents within national borders, governments may artificially bolster the position of domestic firms, for instance, through state aid. Spencer and Brander (1983) offer a theory of government intervention that provides an explanation for industrial strategy: domestic net welfare is improved by capturing a greater share of the output of rent-earning industries. However, this can result in a collectively wasteful subsidy war.

In our contribution, we adopt a different approach and focus on how governmental intervention alters incentives to (1) invest in R\&D in the early phase of the lifecycle and (2) relocate resources in later phases of the lifecycle when the product becomes mature. In our very simple model, firms initially decide whether or not to invest in research, and later on, whether to change activities, given that there are informational spillovers. On the one hand, these spillovers may allow imitation, thus discouraging investment in research. On the other hand, knowledge spillovers are known to be an important location factor in support of regional agglomeration, leading to positive external economies. Hence, there is a dual nature to information spillovers. Accordingly, we assess the impact of subsidizing research during the early stage and protecting firms in mature industries. Subsidies and aid to domestic firms are widespread and may benefit from an exemption from European Commission (EC) rules if they "facilitate the development of certain economic activities (...) or economic areas" (art. 87, EC Treaty). Protection is also far from unusual and the recent merger between the two French firms EDF and Suez, protecting the latter from hostile takeover by non-French 
companies, may provide an example of it. While we obtain theoretical justifications for intervention when assuming benevolent politicians, real-world politicians are more likely to be motivated by re-election concerns. To underline this, we provide illustrations drawn from actual experience of inefficient promotion of national champions.

The remainder of the chapter is organized as follows. Section 2 describes in more detail the way champions operate at different phases of the lifecycle, with a special focus on politician incentive to promote such champions. Section 3 introduces a simple model of a champions-related policy along the lifecycle. Sections 4 and 5 are devoted to realworld illustrations: Section 4 provides examples of the importance of knowledge and its diffusion at a local level, while Section 5 illustrates how the promotion of national champions may stem from private interest, either that of firms near bankruptcy, or that related to large-scale projects with high visibility. Section 6 concludes.

\section{Promoting Champions along a Lifecycle}

\section{Champions in the early phase of the lifecycle}

The early phase of the lifecycle is characterized by experimentation. Here, customer preferences are diverse and entrepreneurial virtues, such as flexibility and openness to the unexpected, are needed to address these preferences. High responsiveness to consumer preferences and willingness to experiment with processes borrowed from other industries are essential to success. This experimentation phase is characterized by high firm turnover, which leads to fruitful innovation, on the one hand, but, on the other 
hand, makes scale economies in production unlikely, a topic well discussed in the "infant industry" literature. The infant industry arguments were initially formulated by Alexander Hamilton at the end of the 18th century, and then expanded by Friedrich List, most particularly in his 1941 book, The National System of Political Economy. John Stuart Mill believed that industries should be protected only temporarily, that is, while they are learning new technologies. More recent studies have defined and restricted the applicability of the theory (see, e.g., Bardhan, 1971). Champions in this early phase of the lifecycle can be described as entrepreneurial firms.

As argued above, politicians seeking reelection are reluctant to have fast but erratic growth and prefer slow but smooth growth (Roe, 2003). They are strongly motivated to smooth the evolution of the early phase of the lifecycle - a process best described as creative destruction. Schumpeter (1942:85) describes it as follows: "But ..., it is not the kind of [price] competition which counts but the competition for the new commodity, the new technology, the new source of supply, the new type of organization (the largestscale unit of control for instance)—competition which commands a decisive cost or quality advantage and which strikes not at the margins of the profits and the outputs of the existing firms, but at their foundations and at their very lives." However, this attempt to smooth the evolution of the early stage of the lifecycle may have severe consequences, and can, ironically enough, even result in destroying the process of creative destruction itself. Seabright (2005) argues that incumbent firms expanding into the infant industry sector are the greatest beneficiaries of public subsidizing as they are already politically well connected, i.e., they are successful lobbyists. Such a policy harms the process of creative destruction in two ways. First, concentrating on incumbent 
firms prevents the positive effects of what Aghion et al. (2008) term "entrycompetition," i.e., competition resulting from the threat of new entry. Furthermore, politicians are reluctant to admit that one of their projects has failed unless they are absolutely forced to by some spectacular or public event. However, allowing projects to fail and disappear is an important part of the process as creative destruction.

\section{Champions in the intermediate phase of the lifecycle}

Once the industry matures, firms having successfully emerged from the early phase of the lifecycle now begin to realize economies of scale in production as the number of product variants narrows. At this stage, firms improve and extend the selected variants in an increasingly routinized and predictable process. At the beginning of this phase, the opportunity for dramatic product improvements (not innovations) along with excess profits attracts new entry. With time, the resulting competition creates a need for constant innovation as the only way to survive. Given the importance of successful innovation, R\&D activities and knowledge production become an internal, bureaucratically controlled process in large firms and their key suppliers. The routinization of the innovation process increases the predictability of its outcome and thus contributes to firm competitiveness (Baumol, 2002a). Towards the end of this phase, products become increasingly routinized and subsequent (incremental) innovations depend largely on previous experience. When combined with decreasing excess profits due to the larger number of market participants, this eventually creates a barrier for new entry. However, internal innovation and scale economies together result in rapidly-growing firms. We call these firms routinized firms. 
In this phase of the lifecycle, politicians, regardless of their reelection goals, have no incentive to intervene as growth is smooth and stable. Routinized firm innovation "tends to be conservative, seeking products whose applicability is clear and whose markets are relatively not speculative. The bureaucratic control typical of innovative activity in the large firm serves to ensure that the resulting changes will be modest, predictable and incremental" (Baumol, 2002b). Accordingly, as firm exit is rare during this intermediate phase of the lifecycle and the number of firms generally increases, there is no need for politicians to interfere or intervene.

\section{Champions in the mature phase of the lifecycle}

In the mature phase of the lifecycle, a small number of product variants dominates the market. Firms now concentrate on process innovation in order to make the production process more effective. These process innovations originate from the firm's internal learning-by-doing. Competitors that cannot keep pace with the speed of process innovation are forced to exit the market.

Some firms in the mature phase of the lifecycle can best be described as big projects, because of their size or because of the media coverage their projects attract. Politician seeking reelection may be inclined to subsidize these big projects in order to prevent their market exit, even though exit and, again, creative destruction is the driving force behind process innovation at this phase of the lifecycle. Seabright (2005) asks: "What do we know about the biases of politicians in selecting investment projects for public support? They tend to be large, they tend to produce products that are highly visible in the press and media (affording many photo-opportunities for the politicians concerned), 
and they tend to be comparatively insulated from competition - both because this makes them less risky to finance and because it avoids awkward questions about their comparative performance with similar projects that do not receive public support."

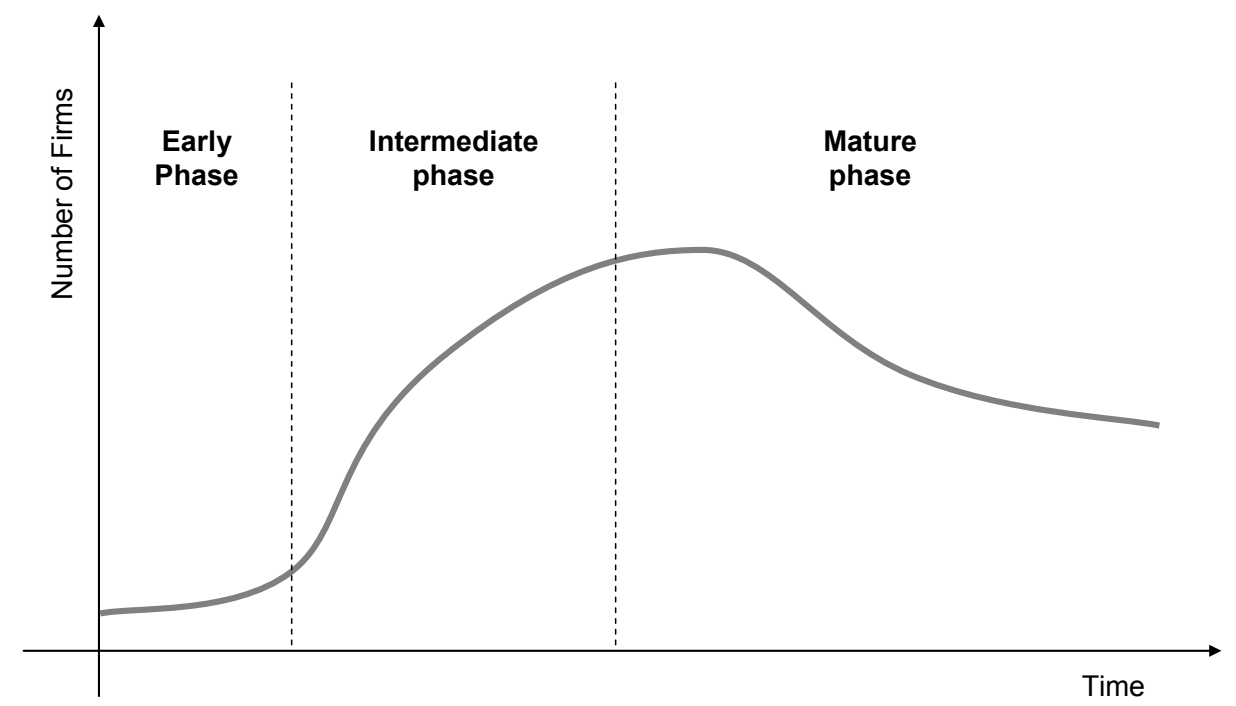

Figure 1: Stages along the lifecycle (Klepper, 1996)

Based on empirical findings by Gort and Klepper (1982), Figure 1 illustrates net firm entry, i.e., changes in the number of firms over time. Assuming that, in the absence of intervention, the number of local firms follows this curve of industry evolution, we obtain the following implications. In the early phase, trial and error stimulate the process of creative destruction, where exit often quickly follows entry. Many firms, in a life or death struggle, are competing to create the dominant product variant which results in a relatively high firm turnover rate during this phase of the lifecycle, and a relatively low number of firms in the market. As this search process brings about winners and losers, we are, again, dealing with a turbulent emerging market, likely to attract political attention. In contrast, the second phase of the lifecycle is already experiencing growth and thus is less likely to be the focus of political attention. Finally, 
the mature phase, where efficiency increases cause firm exit, is, again, a stage at which politicians are likely to feel tempted to intervene.

A major objection against such a national-champions policy is that in a period of global competition, protectionist policies pursued by one country may give rise to the risk of that country falling behind the technology frontier if other countries are relying on competition to spur innovation. Such a noncompetitive environment will not strengthen, but instead actually weaken, the domestic firms. It deters investment and relocation of activities in new products or markets.

To examine these welfare effects more precisely, the following section isolates and formalizes several reasons for subsidizing innovative activities or promoting national champions along the three phases of the lifecycle described above. Under the conditions spelled out below, the promotion of national champions may be welfare-improving from the point of view of the country or region where the national champion is located; however, note that, in reality, a policy of promoting national champions may not be motivated by political benevolence but by rational politicians maximizing their own utility - that is, getting themselves reelected. Thus, our simple analysis provides only an initial framework for classifying benevolent reasons to intervene and promote champions at a theoretical level.

\section{A Simple Model of Intervention in Changing Industries}

We consider a sector in which R\&D is necessary to develop new products. Research has uncertain results and its outcome is initially confidential, but knowledge eventually 
leaks out. This happens, for instance, when employees "job hop" from the innovator to competitors (Fallick et al., 2006) or simply when competitors reverse engineer the innovator's product or service. An innovator is thus initially protected by secrecy, but may later be to some extent expropriated from the research investment as knowledge spills over and competitors copy the technology or product.

\subsection{The model}

\section{The invention of new products}

We consider a regional or local "innovator," for instance, a small or large firm or a researcher teamed up with a venture capitalist. We assume for simplicity that there is only one such local innovator for the market under consideration (and we abstract from internal issues associated with the distribution of rents generated by new ideas, as in e.g., Baccara and Razin, 2007). The innovator has initial assets $A$ and must invest a fixed amount $I, I>0$, in order to develop a new product. Initial assets $A$ may, or may not, be sufficient to finance investment $I$. After $I$ is invested, the innovator privately "invents" a new product with probability $p, 0<p<1$, at Date 0 , in which case she obtains observable profits at Date 1.

At this stage, the product can be copied by other firms, which, for the sake of simplicity, are assumed to all be foreign (or nonlocal); the investor then loses exclusivity in producing the product. We thus assume that perfect protection of intellectual property rights (IPR) is not possible. This is particularly true for noncodifiable knowledge that cannot be described in a patent. At Date 2, there is market competition. At this point, the innovator may either continue production, or relocate her physical assets and skills (i.e., 
her resources) to another activity; this outside option yields expected profits $\underline{\pi}$ and consumer surplus $\underline{C S}$. These levels depend on the degree of asset specificity. In a fully dynamic version of our model, they would be equilibrium values depending on the amount of assets redeployed and the level of skills and know-how prevailing locally. However, this is clearly outside the scope of this chapter, which is why we will consider the outside option benefits as given.

We use $\pi_{1}$ and $\pi_{2}$ to denote the profits made by the inventor, and $C S_{1}$ and $C S_{2}$ to denote local consumer surplus in periods 1 and 2, respectively. Expectations are denoted with operator $E$ (with $E\left(\pi_{2} \mid \pi_{1}\right)$ being the expected value of Date 2 profits given Date 1 profits, for instance).

In addition to consumer surplus and the innovator's profits, local production of the new good may create positive externalities in the area: employees and researchers may benefit from learning-by-doing; the innovation may speed other local research projects, possibly due to knowledge spillovers (Feldman, 1994; Feldman and Audretsch, 1999); local employment may generate complementarities favoring a "big push" (RosensteinRodan, 1943; Murphy et al., 1989). We denote by $L_{i}, L_{i} \geq 0$, the gains associated with these potential externalities at stage $i, i=0,1,2$.

We prefer not to assume that the social value of an activity is correlated with its private value (contrary to e.g., Ades and Di Tella, 1997, in which an increase in investment increases both private and social benefits). Depending on the specific sector considered, externalities and spillovers may be of more or less value at each stage. Investing in innovation (at stage 0) may create a stock of "competencies" and knowledge of value 
for future projects independently from the success or failure of the initial research; this may be particularly likely in the pharmaceutical industry and other industries at the frontier of scientific knowledge. In other sectors, most of the value will arise from developing a particular product, thereby ensuring that the investment has been successful. The benefit then accrues at stage 1, as workers have to create new processes and learn by doing. Externalities obtained from mature production at stage 2 are most likely to be employment related: the specific employment generated in the field may be of additional value, compared to local employment in other sectors, for instance, because employment in this field is a better match with local employee skills, or because new such skills are developed. Such additional benefits are also likely to arise when the region faces high redundancy rates where laid-off employees have difficulty finding new jobs. Note that this last type of externality is the most visible one, and thus may receive excess media attention compared to the two other types.

These externalities may motivate government intervention; Accordingly, we denote $\mathrm{L}=\mathrm{L}_{0}+p L_{1}+p L_{2}$ but also consider the case without externalities $(\mathrm{L}=0)$.

We assume that government is unable to assess the quality of an innovator's "idea"that is, the profits she will make in case of success, $\pi_{1}$ and $\pi_{2}$. This assumption is made for the sake of simplicity but is not completely unrealistic as it can certainly be argued that "innovators" and experts, including specialized venture capitalists, usually have a better understanding of the true potential of a new product, software, technology, and so forth, than do politicians. We rule out the possibility of using a revelation mechanism to obtain this information. In our context, this would require regulation of prices or quantities, which would be quite unusual in the industries we are looking at and 
particularly complex due to the number of competitors; in addition, a government may be unable to regulate firms that are selling, but not producing, domestically (regulating only a fraction of active firms further adds to the complexity of incentive issues, due e.g., to potential collusion - as in Aubert and Pouyet, 2006). We will thus only consider simple instruments.

We assume that there are credit constraints, so that if the innovator has insufficient initial assets, $\mathrm{A}<\mathrm{I}$, borrowing entails costs. We focus on this situation in what follows. The innovator is protected by limited liability such that the opportunity costs of raising funds are normalized to zero. Thus, borrowing on an imperfect credit market entails a cost of $r(I-A)$ per unit borrowed, where $r(\ldots)$ is an increasing function of the amount borrowed, I-A. Borrowing I-A thus imposes a total expected reimbursement of $(I-A)(1+r(I-A)$. Let us denote by $\Pi(I-A)$ the minimum level of profit necessary to be able to pay back borrowings: $p \Pi(\mathrm{I}-\mathrm{A})=(\mathrm{I}-\mathrm{A})(1+\mathrm{r}(\mathrm{I}-\mathrm{A}))$. Given that lenders have complete information on the expected profits, an innovator with an idea yielding profits of $\pi_{1}+\pi_{2}<\Pi(I-A)$ will not receive financing.

\section{$\underline{\text { Governmental intervention }}$}

The "government" is assumed to be benevolent, unless otherwise stated, and cares only for local welfare, not including foreign firm profits (which might be zero anyway, if second-period competition is strong). There are two ways for the government to intervene:

- it can grant a subsidy $s, \mathrm{~s}>0$, to the innovator, 
- or it can protect her from foreign competition.

Protecting the local firm from competition increases her profits from $\pi_{2}$ to $\pi_{2}^{P}$, where $\pi_{2}<\pi_{2}^{p}$. Profits under protection are an increasing function of the value for consumers of the good produced. Protection reduces consumers surplus, as the market is monopolized, from $C S_{2}$ to $C S_{2}^{P}, C S_{2}>C S_{2}^{P}$.

When government grants a subsidy $s$ to innovative activities, we assume that the outside option of relocating allows the firm to obtain a subsidy $\underline{s}$, where $\underline{s}$ may be positive or zero depending on the type of industry considered.

It is clear that government may use both instruments simultaneously. In order to assess their impact, we prefer to compare their relative benefits. Rather than a subsidy, the government may prefer to grant a subsidized loan. Yet as the innovator is protected by limited liability, a loan does not solve potential moral hazard issues, and would not differ much from a subsidy in our subsequent analysis. For clarity, we focus here on the simpler case of a subsidy. Further, we assume that there is no IPR protection that will prevent copying: for instance, the type of innovation considered may not be patentable, or a patent or copyright may not be enforceable worldwide.

The government will choose a level of intervention based on the expected average values of $\pi_{1}, \pi_{2}, \pi_{2}^{P}, \underline{\pi}, C S_{1}, C S_{2}$, and $\underline{C S}$ for the industry considered (as we do not specify functional forms, this computation offers little insight and is not done here). The next subsections investigate how the two policies affect the decision to relocate assets in other activities, and the decision to undertake R\&D. 


\subsection{The decision to redeploy assets}

Let us consider the decision to 'relocate assets' at the end of the first period, that is to use them in an alternative use instead of continuing to produce the now mature product. It would be (locally) socially optimal to relocate whenever $\pi_{2}+C S_{2}+L_{2}<\underline{\pi}+\underline{C S}$. The innovator will decide to relocate whenever $\pi_{2}<\underline{\pi}$ in the absence of protection and subsidization of research, when $\pi_{2}<\underline{\pi}+\underline{s}$ if new research activities are subsidized, and when $\pi_{2}^{P}<\underline{\pi}$ if there is protection. In this context, the last inequality is more demanding than the first, while the second one is less so: subsidization fosters relocation; protection has the opposite effect.

Protection thus has the drawback of delaying the relocation of productive assets and human skills (as exemplified in mining industries in France and the United Kingdom). It may, however, be a beneficial strategy if $L_{2}$ is very large-i.e., local employment is highly valued and cannot be fully relocated $\left(L_{2}\right.$ represents the additional value of employment in the first activity, compared to other local employment opportunities).

Subsidization of research activities may be an efficient strategy if the innovator underinvests in the absence of intervention, which, as we argue below, is likely to be the case, particularly if new activities improve the local stock of knowledge (high externalities, $L_{0}+L_{1}$ ). Yet in some settings, subsidization may have the adverse effect of inducing inefficient relocation. However, this impact may be of limited consequence when one considers consumer welfare alone (when $L_{2}$ is close to zero), as consumers will be served by foreign firms. Subsidization thus seems to fare better than protection 
with respect to asset relocation decisions unless it involves lasting local unemployment or disqualification $\left(L_{2}\right.$ is high).

\subsection{The decision to undertake research}

It would be optimal (from the local social welfare perspective) to invest in research whenever

$$
p\left[\pi_{1}+C S_{1}+\max \left\{\pi_{2}+C S_{2}-(\underline{\pi}+\underline{C S}), 0\right\}+L_{1}+L_{2}\right]+L_{0} \geq I .
$$

Yet, the innovator would decide, in the absence of government intervention, to conduct research if and only if

$$
p\left[\pi_{1}+\max \left\{\pi_{2}-\underline{\pi}, 0\right\}\right] \geq I+(I-A) r(I-A) .
$$

Several reasons may justify government intervention:

- Imperfect market competition: As the market is monopolized in the first period, and unless the innovator is able to perfectly price discriminate, the innovator's profits are lower than social welfare $\left(C S_{1}>0\right)$ and innovation may not occur frequently enough. This also holds in the second period if competition remains imperfect after the entry of foreign competitors.

- Imperfect credit markets: Financing costs above the opportunity cost of funds may dissuade investment in a socially optimal activity. This happens if condition (1) is satisfied, but would not be the case if a financing cost $(I-A) r(I-A)$ was added to the real investment cost $I$. 
- Local spillovers: Last, obviously, if there are strictly positive externalities at any stage $(L>0)$, then the innovator can not internalize the positive externalities of information leakage and of local employment, and may not innovate enough (she may also relocate too often as we have seen).

All these scenarios imply that, from the local welfare perspective, the level of R\&D is too low.

\section{$\underline{\text { Innovation under subsidization of research activities }}$}

The potential innovator will invest $I$ in $\mathrm{R} \& \mathrm{D}$, under a subsidy, if and only if

$$
p\left[\pi_{1}+\max \left\{\pi_{2}-(\underline{s}+\underline{\pi}), 0\right\}\right] \geq I-s+(I-s-A) r(I-s-A) .
$$

Clearly, subsidization offers an immediate net gain to the investor as it reduces the interest rate, making more projects viable. It is particularly beneficial for small firms that have low levels of initial assets to be invested and also suffer from credit constraints. It has, however, the drawback of potentially inducing overinvestment, particularly by large firms that already have low interest rates thanks to self-financing.

As with any type of grant, a subsidy may give rise to moral hazard, with beneficiaries diverting monetary resources to activities other than the one intended to be subsidized. We will briefly discuss but not model moral hazard although the issue is of interest, and may be why there are imperfect credit markets in the first place. We have chosen to focus here on externalities in the process of innovation. 
$\underline{\text { Innovation under protection of mature firms }}$

The potential innovator will invest if and only if

$p\left[\pi_{1}+\max \left\{\pi_{2}^{P}-\underline{\pi}+, 0\right\}\right] \geq I+(I-A) r(I-A)$.

Protection from foreign competition is of more or less value depending on the firm's expectations about its product's value in the second period or, more precisely, of $\pi_{2}^{P}$, which increases with this value. Protection has no impact if the firm expects to relocate in the second period (a decision that may, however, be less often chosen under protection). Protection may foster investment in projects that have a high second-period value. It may thus allow for a better screening of projects in terms of their expected value.

In addition, protection will allow a firm to obtain financing when its profits in the absence of protection were too low to ensure loan repayment: $\pi_{1}+\max \left\{\pi_{2}, \underline{\pi}\right\}<\Pi(I-A) \leq \pi_{1}+\pi_{2}^{P}$, where $\Pi(I-A)=[I+(I-A) r(I-A)] / p$. This aspect of protection has greater impact for innovators with small initial resources $A$, and less for sectors in which innovations are undertaken by large firms.

\subsection{A discussion of some issues}

\section{Protection and the cost of public funds}

We have seen that protection tends to inefficiently delay relocation of assets, particularly if there are few externalities in mature industries. However, there is one argument in favor of using the protection strategy, an argument that is particularly 
relevant in the case of less developed countries. If using public funds to subsidize is costly, then protection of mature industries may be preferred. This effect should not be ignored. Spending one dollar on subsidies actually costs one dollar plus an amount called "the cost of public funds," which represents, among other things, administrative costs, the distortionary impact of taxation, tax evasion, and corruption, and the shadow cost of the state's budget constraint. It is generally believed that this cost of public funds is around 0.3 for the United States, between 0.3 and 0.5 for European countries and Japan, and above 0.7 for less developed countries (Laffont and Tirole 1993). In less developed countries, administrative costs tend to be high, corruption is more widespread, and the opportunity value of funds is also quite high. Indeed, Auriol and Warlters (2005) estimate that the cost of public funds amounts to 1.17 for 38 African countries. This high cost may explain why many less developed countries are particularly interested in protecting their domestic markets.

Note in this context that moral hazard is more likely to raise issues in developing countries than in more developed countries (though this is not always true). If information asymmetries are more severe in LDCs, subsidies are at a higher risk of being misused - contrary to protection for which money diversion is not an issue.

\section{$\underline{\text { Non-benevolent governments }}$}

When governments cannot commit, extortion or hold-up of firms' profits is an issue 'as in Ades and Di Tella (1997). In our context, fear of extortion would deter investment in innovation. It may also delay redeployment of assets if the new activity is more prone to extortion. Firm owners and managers may be expected to value non-monetary benefits (that cannot be seized by the government) relatively more than profits; this might favor 
resources diversion at the innovation stage, and no redeployment during the mature phase. The value of subsidization is reduced from the point of view of the government as a non-negligible part of the subsidy is likely to be diverted. This issue is likely to be more relevant for some developing countries that have weak institutions.

In democratic regimes, reelection concerns may also distort policies. Redundancy and bankruptcy attract media attention and may have an adverse and immediate impact on a politician's chances of reelection. Anticipating this, the head of the government may prefer to support less risky projects or protect employment and ownership in mature industries. Spending time or money on firms in the early phases of the lifecycle, that is more useful for small firms than large ones, is less likely to attract attention and has medium- or long-run effects only. Protecting mature industries may thus appear a more attractive option, especially as it will protect against unemployment risk, which many politicians consider the death knell of their careers.

A concern for reelection, as it would lead to protecting mature firms, could be formally similar to the government associating an excessively high value to $L_{2}$. If this value is higher than its true level, there would be an over-emphasis on policies that delay asset relocation leading to inefficient, excess stability in the local industry. In the long run, this would deter innovation and impede growth in the region, as the products of mature firms eventually become obsolete, while only few local firms innovate.

When foreign firm competition intensifies, though, as happens under increased globalization, protecting mature industries becomes particularly costly in terms of welfare. In this context, Aghion et al. (2008) introduce the notion of an escapecompetition effect where constant innovation is the only way to escape competition, 
secure a stable market position, and guarantee at least a certain level of employment. An in-depth analysis of the motivations of a nonbenevolent government is outside the scope of our simple model, but we return to this issue in Section 5, with real-life examples.

\section{A summary}

To summarize, protection from competition can generally be regarded undesirable as it is likely to cause inefficiencies in the relocation of resources. An exception is the case when externalities generated by mature firms $\left(\mathrm{L}_{2}\right.$ high) would be lost when relocating the workforce. For instance, this may occur in downsizing sectors already marked by high unemployment and where workers are highly specialized. Here, protection could be used to protect employees from unemployment and all the related social costs unemployment brings. Protection from competition may also be optimal for developing countries that lack financial resources to use other promotion tools. Last, protection may also be useful when subsidies are likely to be diverted from innovation activities because of moral hazard: in order to benefit later from protection, the firm must innovate now to obtain an incumbency in the future. Protection thus reinforces incentives to invest, contrary to subsidies, which have value both as means of investment, and as resources to be diverted from innovation activities.

Subsidies may be optimal for industries undertaking high-tech and long-term or fundamental research, i.e., those industries in which much value is created by simply searching for an invention, even though the knowledge acquired along the way may not be directly useful to a particular innovation ( $L_{0}$ high). However, subsidization is not necessary when innovation is undertaken by large firms, or by subsidiaries of such firms, that do not face credit constraints. 
In practice, the most visible government intervention tends to involve the protection of mature industries, possibly due to reelection concerns, as we discuss in Section 5. These firms are unlikely to face much credit constraint and may not generate as many externalities as less visible firms; their protection is thus likely to be excessive under non benevolent politicians. It is likely that voters are more aware of the short-term social adjustment costs incurred by allowing a mature firm to go bankrupt or undergo important restructuring, than they are of the long-term competitive benefits achieved through improving local knowledge stocks and hence being innovative at the

technology frontier. As a consequence, protection becomes a more attractive policy for rational politicians seeking reelection.

\section{The Importance of Local Knowledge and Research}

Developing production processes and human capital involves important externalities, as has been shown by the success of high-tech "belts." A closer examination of these examples highlights how internal organization and institutions have played a role in this success, which are exactly the type of externalities we have in mind when we refer to “externalities at the development stage," denoted $L_{1}$. For instance, Rosenberg (1990) attributes the success of the best private research laboratories (e.g., Bell Labs., IBM, Dupont, Dow Chemical, Eastman Kodak), and the appropriability of the fruits of their research, to the close intellectual proximity maintained between the basic research laboratories and the development and production wings of these firms (Dasgupta, 1988). 
A comparison of the famous Silicon Valley in California with Route 128 in Boston, Massachusetts, is particularly interesting. Both are high-tech districts, but they evolved in widely divergent ways. In 1965, Route 128 had approximately three times more hightechnology employment than did Silicon Valley. Today, however, Silicon Valley is way, way ahead in the high-tech game. Saxenian (1994) attributes Silicon Valley's success to two major differences between it and Route 128. First, companies in Silicon Valley relied on vertical disaggregation, from which emerged competing modular suppliers (Baldwin and Clark, 1997:85), whereas companies along Route 128 focused on vertical integration. Second, technological knowledge diffused much more rapidly in Silicon Valley than along Route 128.

Knowledge diffusion is a double-edged sword. Rapid knowledge diffusion undermines the appropriability of "exclusive" rents arising from the lock in of knowledge. However, knowledge diffusion across a network of firms can act as a multiplier, resulting in the creation of new knowledge and, therefore, additional but "collective" rents open to all network participants. Of course, whether this multiplier is a benefit is criticaly dependent on the extent to which the individual (or firm) will have access to the collective rents, i.e., the intensity of knowledge diffusion. Implicit and explicit institutions play an important role in this context as they can provide a foundation for trust in reciprocity, which will help assure that each network member is willing to feed the network with new knowledge (Powell, 1990).

Job hopping is one of the simplest methods of knowledge diffusion. Gilson (1999) and Hyde (2003) argue that the only way this type of knowledge diffusion can be stopped is by means of a post-employment covenant not to compete. Employees who enter into such covenants are not permitted to work for competitors for a fixed length of time 
(usually two years) after termination of employment for any reason. Returning to the Silicon Valley vs. Route 128 example, it is interesting that Massachusetts allows noncompete covenants but California does not. Accordingly, "any firm connected to the personal networks through which information and employees flowed in Silicon Valley could benefit from the best innovation produced in the entire cluster rather than the best innovation produced by their own, proprietary research and development efforts" (Fallick et al., 2006).

The Silicon Valley example highlights the advantage of unhampered knowledge flows over restricted knowledge flows within a regional network. In Silicon Valley, the absence of legal restrictions on job mobility led to a vertical disintegrated business culture of coopetition. Firms cooperate in creating a regional knowledge stock that, in turn, becomes the foundation of their competitiveness in global markets. Knowledge came to be seen as a regional club good and each company connected to the network could benefit from it. This resulted in a regional "standing-on-shoulders" effect that gained companies a competitive advantage over regions where companies could build only on their own internal knowledge. However, such an environment can exist only when there is trust in reciprocity (Powell, 1990), i.e., the absence of free-riding. Every rational company would desire to benefit from other firms' ideas and knowledge circulation within the network while, at the same time, locking in its own knowledge. If this was a dominant strategy, the regional standing-on-shoulders effect would not occur. However, if the law eliminates the possibility of locking in knowledge-as in California-cooperation becomes the dominant strategy and thus helps overcome problems of collective action that would eventually produce a regional disadvantage. In 
the absence of external institutions, social sanctions, acting as a kind of informal institution, can produce the same result (Ellickson, 1991).

Given the comparative advantage of regional cooperation over isolation, it becomes desirable to engage in a network strategy such that it is in each company's own interest to cooperate, leading to an intense flow of knowledge. However, in the absence of explicit institutions, there is a risk of free-riding that can be avoided only by adequate implicit trust-supporting institutions. Depending on the regional network's structure, there are two ways of generating trust, both relying on a firm's regional embeddedness. In networks of equals (i.e., small and medium-sized firms) where firms are usually owner led, trust results from the owner's regional embeddedness and his or her social ties. The literature on industrial districts (Piore and Sable, 1984; Becattini, 1990) highlights the advantages of coopetition resulting from trust in reciprocity due to strong social ties. The stronger the social ties within a network, the higher the probability of being caught out as a free-rider. If free-riding leads to an exclusion from the network, its costs usually exceed its benefits. Well-known examples of districts using social ties as a regulation are the textile and leather industry in northern Italy and manufacturing industry in southern Germany. These strongly export-oriented manufacturing sectors with many small and medium-sized companies, often family-owned, are highly specialized and yet competitive in the global market. However, as they usually serve niche markets, they are not highly visible and are rather "hidden champions." In the case of hierarchical networks dominated by a large firm, trust does not prevail per se. Large companies' organizational structures are usually not compatible with relationships based on social ties. In this environment, the big player's potential to become a real champion is determined by its ability to act as a network pilot. As a 
network pilot, the real champion needs to convince other firms in the region of the network's profitability. To do so, game theory would suggest the importance of a positive signal, usually some kind of self-commitment, from the network pilot. In giving this signal, the network pilot demonstrates its commitment to the network and thus contributes to strengthening and expanding the network. This idea is complementary to the French view of a national champion which stresses such an entity's social responsibility. Social responsibility should be understood as all efforts contributing to build up, foster, and intensify the network.

Thus, once a network pilot has managed to build up a regional network, i.e., the network pilot has gained other companies' trust, additional social responsibilities come into play. At this point, the entire network of firms needs to engage in various regional activities so as to stimulate regional dynamics and thus generate positive externalities for its members. With regard to network care and development, the network pilot may still bear most of the responsibility, but maintaining the network is in the pilot's own selfinterest and thus the costs of the obligation (time and expense) can be justified. However, to create and maintain an all-embracing regional network, the large company members must not be too dominant and positive externalities from participating must be perceptible to all members, independent of size. This is especially important as small companies are believed to be a driving force of innovation (Audretsch, 1995). Thus, supporting small companies and startups means that fresh knowledge will be produced, eventually increasing the network's pool of knowledge. One way to contribute to knowledge production is to provide corporate venture capital to startups (Gompers, 2002); another way is to join forces with universities. 
Other social responsibilities profitably engaged in by a regional network of firms might include sponsoring and donating to cultural institutions, e.g., festivals, concerts, exhibitions, and other bohemian projects in the region. This activity will enhance a region's amenities and make it more attractive to creative persons or those with high potential, thus not only keeping the current labor pool in place but expanding it with highly skilled workers (Glaeser et al., 2001; Florida, 2002).

\section{Strategic and Political Reasons to Promote Champions}

\subsection{Supporting the Lame Ducks}

As discussed in Section 3, it may be welfare-increasing to protect mature firms in the presence of specialized employment, tacit knowledge, and local networks. However, there may be other, nonbenevolent reasons why a public authority may want to intervene and favor insufficiently competitive firms (lame ducks).

$\underline{\text { Strategic trade policy or how to beggar your neighbor }}$

One argument for supporting "lame ducks" is found in the strategic trade policy literature. Let us assume that there is a market for some arbitrary good. The market is characterized by worldwide imperfect competition and suppliers from around the world compete to capture excess rents. To retain the largest possible share of the excess rents within national borders, governments may be inclined to artificially bolster the position of domestic firms in this market, perhaps through state aid. As mentioned in the introduction, Spencer and Brander (1983) presented a theory of government intervention explaining industrial strategy. Positive welfare effects from subsidization of local firms are not guaranteed, for at least two reasons. First, local firms operating in 
imperfect markets do not earn excess rents only from foreign markets but also from home markets, leading to a loss of consumer surplus in the home country. This is reflected by $C S_{2}^{P}<C S$ in our model. Second, the subsidy-ridden noncooperative international equilibrium is suboptimal, leading to subsidy wars. The multilateral prohibition of subsidies, should such an agreement prove possible, would increase the welfare of all countries.

\section{$\underline{\text { National champions are mortal }}$}

Another argument for protecting established firms in the temporary presence of sizable externalities (i.e., $L_{2}$ becomes negligible with time) involves structural change and unemployment. Cohen (1995:30) states that "there is little need to dwell upon the lame ducks other than to remind the reader that a national champion is mortal." A dynamic economy, by definition, undergoes constant structural change, due, among other things, to different industry growth rates of production and demand (for an overview, see Pianta and Vivarelli, 2007). Structural change has geographical implications, too, as industries are not evenly distributed geographically (for a European discussion, see MidelfartKnarvik and Overman, 2002). Industries that do not change and grow will eventually die. This will, obviously, have serious negative effects on employment in the short-run but industry death can have long-term effects on employment too, particularly when the labor market is inflexible and immobile (externality $L_{2}$ in our model). In this situation, state intervention can merely delay the inevitable, but politicians, with short-term horizons, especially when up for reelection, may wish to smooth out the process of decline and thus ease social tension. A famous example is former German Chancellor Gerhard Schröder's 1999 attempt to rescue one of the biggest construction companies in 
Germany_Philipp Holzmann AG. Due to mismanagement and a far-too-optimistic view concerning a possible construction boom in Eastern Germany, Philipp Holzmann AG accumulated more than 2.4 billion German marks of debt, which put the firm's survival in great danger. In a highly visible and celebrated move, Chancellor Schröder offered debt guarantees from the state. However, the firm's death was only delayed, not averted, and in early 2002, Philipp Holzmann AG went bankrupt.

This "save the lame duck at all costs" phenomenon is also found in the banking sector, as reported by Vives (2001). Politicians are apparently very taken with the idea that a national champion in the form of a bank must not be allowed to fail as the fallout would be so bad for national industry. Particularly large banks are believed to be "too big to fail." This was the case for the French Credit Lyonnais, which began to founder in the early 1990s due to poor management and fraud (Vives 2001), but was not allowed to die a natural death. This sort of big champion is indeed mortal, but because it is "too big to fail," it becomes a big-project firm, as discussed next.

\subsection{The temptation to support "big-project" firms}

\section{High visibility}

The French Concorde project is an excellent example of Seabright's (2005) point that politicians are tempted to select for public investment support those projects that are both highly visible in the media and comparatively insulated from competition. Being more or less isolated from competition, the project failed because it was more engineerthan customer-driven. Another example is the European Airbus project. The Airbus project has been celebrated in the media as a shining example of successful European champion-oriented industrial policy. Indeed, there is a simulation study by Neven and Seabright (1995) concluding that Airbus was likely to earn a comfortable rate of return 
on the public investment made. Thus, it was a good investment from a pure rate of return perspective. However, the effect of Airbus' entry on consumer surplus is not clear: the gains from competition may be offset by lost economies of scale and the Airbus-induced exit of McDonnell-Douglas. In our model, we assume that competition benefits consumer welfare, $C S_{2}^{P}<C S_{2}$, as this is the most common case (all potential beneficial effects from protection are embedded in profits $\pi_{2}^{P}$ and externalities $L_{2}$ ). In the absence of competition, however, there is no guarantee that the benefits from economies of scale will be passed on to consumers.

\section{$\underline{\text { Strategic industries and security of supply }}$}

Yet another reason advanced for government intervention has to do with security of supply. Strategic industries that secure national supply with essential resources produce an externality $L_{2}$ different form employment that might also justify state intervention. Take the European gas market as an example. Only a small fraction of total European gas consumption is actually produced in Europe. Much of the gas is imported from politically unstable countries, making disruption of supply quite possible. Gas is mainly transported via inter-urban pipelines, another source of risk, both political and physical. Moreover, construction of pipelines results in high sunk costs. As national production is limited, the only way to reduce these risks is to diversify gas imports, that is, build more pipelines, leading, of course, to even higher sunk costs. Therefore, it is often argued that a national or European firm (a heavyweight champion) is needed to guarantee the security of gas supply. And, it then seems acceptable that a vertically integrated gas supplier will earn excess profits from consumers on its home market to compensate it for investing in the very expensive, but necessary for diversity and safety, pipelines and 
other infrastructure. Indeed, this argument was viewed favorably and perhaps had a hand in the eventual approval of the merger of E.ON and Ruhrgas. E.ON, already one of Germany's largest energy companies, intended to acquire a $60 \%$ majority in the gas company Ruhrgas, resulting in E.ON/Ruhrgas becoming Europe's biggest energy company. Preliminarily, permission for the merger was denied by the Federal Cartel Office on the grounds that the merger would have detrimentally strengthen E.ON's already dominant position. However, the merger gained ministerial approval for reasons of security of supply (for details, see Sinn 2002).

Nevertheless, natural monopolies (characterized by high sunk costs) can erode over time- especially through technical progress. The supply of liquefied natural gas (LNG), which is transported by specially designed sea vessels and road tankers, may, in the future, increase, thus diversifying gas supply and reducing reliance on pipelines, making state protection of the pipeline owners (the heavyweight champions) less desirable, a turn of events predicted by our model: protection delays relocation decisions.

\section{Conclusion}

The aim of this contribution was to provide a different approach from that usually found in the literature on national-champion-oriented policies. While the existing literature mainly concentrates on the distribution of rents, we look at their creation. In doing so, we adopt an evolutionary perspective and consider how government intervention along the product lifecycle can alter a firm's incentives to (i) invest in R\&D in the early phase of the lifecycle and (ii) relocate resources during later phases of the lifecycle when the product is mature. In a simple model, we analyze a firm's decision on whether or not to 
invest in research, given that there are knowledge spillovers. Such spillovers carry the risk of imitation by foreign firms, and that discourages research investment. Yet knowledge spillovers also play an important role in geographical location decisions to the extent that they generate positive regional externalities.

We assess the impact of subsidizing research during early stages of the lifecycle and the impact of protecting firms in mature industries. We find certain situations where subsidization of SMEs is an efficient strategy, including those cases (1) where credit constraints prevent small and medium-sized firms from entering the market, thus hindering the positive entry competition effect, and (2) where subsidies have a multiplicative effect by creating spillovers in the early phase of the lifecycle. Protection from competition may also be efficient when public funds are costly or when monetary resources may be diverted rather than invested. However, note that these findings are only applicable to competitive economies at the technology frontier and under the assumption of a benevolent government. Our real-world examples show that subsidizing historically produced undesired results as politicians seeking reelection concentrated on protecting firms in the mature phase of the lifecycle. This evidence suggests a skeptical view of the value of protection and such a policy should be approached with great caution, especially during an election cycle when the assumption of a "benevolent" politician might be particularly inadequate.

Supra-national bodies such as the European Union may limit the discretion of politicians, and mutual scrutiny from its members may be useful in this context. However, indirect promotion, by means of providing an innovation-supportive environment, may hold greater promise. A proper environment may include local 
transportation infrastructure along with supporting institutions such as business incubators, universities, research institutes, etc.; that is, institutions that support local knowledge flows but whose products benefit the entire region, not just one company. This kind of policy, which is aimed at local championship instead of national or European champions, is becoming increasingly popular and is known as cluster-oriented policy (Porter, 1998). 


\section{References}

Ades, A., \& R. Di Tella (1997), "National Champions and Corruption: Some Unpleasant Interventionist Arithmetic", The Economic Journal 107 1023-1042.

Aghion P., R. Blundell, R. Griffith, P. Howitt, \& S. Prantl (2008), The Effects of Entry on Incumbent Innovation and Productivity. The Review of Economics and Statistics, forthcoming.

Aubert, C., \& J. Pouyet (2006), "Incomplete Regulation, Market Competition and Collusion", Review of Economic Design 10 113-142.

Audretsch, D. B. (1995), Innovation and Industry Evolution, Cambridge, MA: MIT Press.

Auriol, E., \& M. Warlters (2005), The Marginal Cost of Public Fund in Africa, IDEI Working Paper 371.

Baccara, M., \& R. Razin (2007), "Bargaining Over New Ideas: The Distribution of Rents and the Stability of Innovative Firms", Journal of the European Economic Association 5 1095-1129.

Baldwin, C. Y., \& D. B. Clark (1997), "Managing in an Age of Modularity," Harvard Business Review Sept.-Oct. 84-93.

Bardhan, P. K. (1971), "An Optimum Subsidy to a Learning Industry: An Aspect of the Theory of Infant Industry Protection,” International Economic Review 12 54-70.

Baumol, W. (2002a), The Free-Market Innovation Machine: Analyzing the Growth Miracle of Capitalism, Princeton: Princeton University Press.

Baumol, W. J. (2002b), "Entrepreneurship, Innovation and Growth: The David-Goliath Symbiosis," Journal of Entrepreneurial Finance and Business Ventures 7 1-10.

Becattini, G. (1990), "The Marshallian Industrial District as a Socio-Economic Notion," in Industrial Districts and Inter-firm Co-operation in Italy, F. Pyke, G. Becattini, \& W. Sengenberger, Eds., Geneva: International Institute for Labour Studies, pp. $37-51$.

Cohen, E. (1995), "France: National Champions in Search of a Mission," in Industrial Enterprise and European Champions, J. Hayward, Ed., Oxford: Oxford University Press, pp. 23-47.

Dasgupta, P. (1988), "The Welfare Economics of Knowledge Production," Oxford Review of Economic Policy 4 1-12.

Dewatripont, M., \& P. Seabright (2006), "Wasteful Public Spending and State Aid Control," Journal of the European Economic Association 4 513-522.

Ellickson, R. (1991), Order Without Law, Cambridge, MA: Harvard University Press. 
Fallick, B., C. A. Fleischman, \& J. B. Rebitzer (2006), "Job-Hopping in Silicon Valley: Some Evidence Concerning the Microfoundations of a High-Technology Cluster," Review of Economics and Statistics 88 472-481.

Feldman, M. (1994), The Geography of Innovation, Boston: Kluwer Academic Publishers.

Feldman, M., \& D. B. Audretsch (1999), "Innovation in Cities: Science-Based Diversity, Specialization and Localized Competition," European Economic Review 43 409-429.

Florida, R. (2002), The Rise of the Creative Class, New York: Basic Books.

Gilson, R. J. (1999), "The Legal Infrastructure of High Technology Industrial Districts: Silicon Valley, Route 128, and Covenants Not to Compete," New York University Law Review 74 575-629.

Glaeser, E., J. Kolko, \& A. Saiz (2001), "Consumer City," Journal of Economic Geography $127-50$.

Gompers, P. A. (2002), "Corporations and the Financing of Innovation: The Corporate Venturing Experience," Federal Reserve Bank of Atlanta Economic Review 87 117.

Gort, M., \& S. Klepper (1982), "Time Paths in the Diffusion of Product Innovations," Economic Journal 92 630-653.

Hyde, A. (2003), Working in Silicon Valley: Economic and Legal Analysis of a HighVelocity Labor Market, M.E. Sharpe.

Klepper, S. (1996), "Entry, Exit, Growth, and Innovation Over the Product Life Cycle", The American Economic Review 86 562-583.

Klepper, S. (1997), "Industry Life Cycles”, Industrial and Corporate Change 6 145181.

Laffont, J.-J., \& J. Tirole (1993), “Cartelization by Regulation,” Journal of Regulatory Economics 5 111-130.

Maincent, E., \& L. Navarro (2006), A Policy for Industrial Champions: From Picking Winners to Fostering Excellence and the Growth of Firms, Industrial and Economic Reforms Paper 2, Enterprise and Industry Directorate-General.

Midelfart-Knarvik, K., \& H. Overman (2002), "Delocation and European Integration: Is Structural Spending Justified?” Economic Policy 35 321-359.

Murphy, K.M., A. Shleifer, \& R.W. Vishny (1989), "Industrialization and the Big Push," The Journal of Political Economy 97 1003-1026.

Neven, D., \& P. Seabright (1995), "European Industrial Policy: The Airbus Case," Economic Policy 21 313-358. 
Pianta, M., \& M. Vivarelli (2007), Unemployment, Structural Change, and Globalization, International Labour Organization.

Piore, M., \& C. Sabel (1984), The Second Industrial Divide. Possibilities for Prosperity, New York: Basic Books Inc.

Porter, M. E. (1998), On Competition, Boston: Harvard Business School Press.

Powell, W. (1990), "Neither Market nor Hierarchy: Network Forms of Organization," Research in Organizational Behaviour 12 295-336.

Roe, M. (2003), Political Determinants of Corporate Governance, Oxford: Oxford University Press.

Rosenberg, N. (1990), "Why Do Companies Do Basic Research (with Their Own Money)?" Research Policy 19 165-174.

Rosenstein-Rodan, P. N. (1943), "Problems of Industrialisation of Eastern and SouthEastern Europe," Economic Journal 53 202-211.

Saxenian, A. (1994), Regional Advantage: Culture and Competition in Silicon Valley and Rte. 128, Cambridge, MA: Harvard University Press.

Schumpeter, J. A. (1942), Capitalism Socialism and Democracy, New York: Harper \& Brothers Pub.

Seabright, P. (2005), "National and European Champions-Burden or Blessing?" CESifo Forum 2/2005 52-55.

Sinn, H. W. (2002), Fusion E.ON-Ruhrgas - Die volkswirtschaftlichen Aspekte, ifo Forschungsbericht 9.

Spencer, B., \& J. Brander (1983), "International R\&D Rivalry and Industrial Strategy," Review of Economic Studies 50 707-722.

Vives, X. (2001), "Restructuring Financial Regulation in the European Monetary Union," Journal of Financial Services Research 19 57-82. 


\section{CESifo Working Paper Series}

for full list see www.cesifo-group.org/wp

(address: Poschingerstr. 5, 81679 Munich, Germany, office@cesifo.de)

2317 Michael Hofmann, Gerhard Kempkes and Helmut Seitz, Demographic Change and Public Sector Budgets in a Federal System, May 2008

2318 Paul De Grauwe, Macroeconomic Modeling when Agents are Imperfectly Informed, June 2008

2319 Johann K. Brunner and Susanne Pech, Optimum Taxation of Inheritances, June 2008

2320 Thomas Eichner and Marco Runkel, Corporate Income Taxation of Multinationals in a General Equilibrium Model, June 2008

2321 Rainald Borck and Matthias Wrede, Subsidies for Intracity and Intercity Commuting, June 2008

2322 Patricia Apps and Ray Rees, Testing the Pareto Efficiency of Household Resource Allocations, June 2008

2323 Amihai Glazer, Vesa Kanniainen and Panu Poutvaara, Firms' Ethics, Consumer Boycotts, and Signalling, June 2008

2324 Claudia M. Buch, Jörg Döpke and Kerstin Stahn, Great Moderation at the Firm Level? Unconditional vs. Conditional Output Volatility, June 2008

2325 Helmuth Cremer, Philippe De Donder, Dario Maldonado and Pierre Pestieau, Forced Saving, Redistribution and Nonlinear Social Security Schemes, June 2008

2326 M. Hashem Pesaran and Paolo Zaffaroni, Optimal Asset Allocation with Factor Models for Large Portfolios, June 2008

2327 Harald Badinger and Peter Egger, Horizontal versus Vertical Interdependence in Multinational Activity, June 2008

2328 Jan K. Brueckner and Harris Selod, A Theory of Urban Squatting and Land-Tenure Formalization in Developing Countries, June 2008

2329 Paolo M. Panteghini, Corporate Debt, Hybrid Securities and the Effective Tax Rate, June 2008

2330 Guglielmo Maria Caporale, Juncal Cuñado and Luis A. Gil-Alana, Modelling Long-Run Trends and Cycles in Financial Time Series Data, June 2008

2331 Avi Ben-Bassat and Momi Dahan, Social Identity and Voter Turnout, June 2008 
2332 Martin R. West and Ludger Wößmann, "Every Catholic Child in a Catholic School”: Historical Resistance to State Schooling, Contemporary Private Competition, and Student Achievement across Countries, June 2008

2333 Erkki Koskela and Panu Poutvaara, Outsourcing and Labor Taxation in Dual Labor Markets, June 2008

2334 Philippe Choné and Laurent Linnemer, Optimal Litigation Strategies with Signaling and Screening, June 2008

2335 Albert Solé-Ollé and Pilar Sorribas-Navarro, Does Partisan Alignment Affect the Electoral Reward of Intergovernmental Transfers?, June 2008

2336 Antonio Cabrales and Piero Gottardi, Markets for Information: Of Inefficient Firewalls and Efficient Monopolies, June 2008

2337 Sumon Majumdar and Sharun W. Mukand, The Leader as Catalyst - on Leadership and the Mechanics of Institutional Change, June 2008

2338 Ulrich Hange, Tax Competition, Elastic Labor Supply, and Growth, June 2008

2339 Guy Laroque and Bernard Salanié, Does Fertility Respond to Financial Incentives?, June 2008

2340 Adriano Paggiaro, Enrico Rettore and Ugo Trivellato, The Effect of Extending the Duration of Eligibility in an Italian Labour Market Programme for Dismissed Workers, June 2008

2341 Helmut Seitz, Minimum Standards, Fixed Costs and Taxing Autonomy of Subnational Governments, June 2008

2342 Robert S. Chirinko, Leo de Haan and Elmer Sterken, Asset Price Shocks, Real Expenditures, and Financial Structure: A Multi-Country Analysis, July 2008

2343 Wolfgang Leininger, Evolutionarily Stable Preferences in Contests, July 2008

2344 Hartmut Egger and Udo Kreickemeier, Fairness, Trade, and Inequality, July 2008

2345 Ngo Van Long and Bodhisattva Sengupta, Yardstick Competition, Corruption, and Electoral Incentives, July 2008

2346 Florian Baumann, Employment Protection: The Case of Limited Enforceability, July 2008

2347 Alessandro Balestrino, Cinzia Ciardi and Claudio Mammini, On the Causes and Consequences of Divorce, July 2008

2348 Dirk Schindler and Benjamin Weigert, Insuring Educational Risk: Opportunities versus Income, July 2008 
2349 Lammertjan Dam and Ben J. Heijdra, The Environmental and Macroeconomic Effects of Socially Responsible Investment, July 2008

2350 Avner Greif, Contract Enforcement and Institutions among the Maghribi Traders: Refuting Edwards and Ogilvie, July 2008

2351 Helmuth Cremer, Philippe De Donder, Dario Maldonado and Pierre Pestieau, Habit Formation and Labor Supply, July 2008

2352 Francesco Menoncin and Paolo M. Panteghini, The Johansson-Samuelson Theorem in General Equilibrium: A Rebuttal, July 2008

2353 Michael Kaganovich and Itzhak Zilcha, Alternative Social Security Systems and Growth, July 2008

2354 Keith Blackburn, Kyriakos C. Neanidis and M. Emranul Haque, Corruption, Seigniorage and Growth: Theory and Evidence, July 2008

2355 Edward Castronova, A Test of the Law of Demand in a Virtual World: Exploring the Petri Dish Approach to Social Science, July 2008

2356 Harald Badinger and Peter Egger, GM Estimation of Higher-Order Spatial Autoregressive Processes in Cross-Section Models with Heteroskedastic Disturbances, July 2008

2357 Wolfgang Buchholz and Jan Schumacher, Discounting the Long-Distant Future: A Simple Explanation for the Weitzman-Gollier-Puzzle, July 2008

2358 Luca Anderlini, Leonardo Felli and Alessandro Riboni, Statute Law or Case Law?, July 2008

2359 Guglielmo Maria Caporale, Davide Ciferri and Alessandro Girardi, Are the Baltic Countries Ready to Adopt the Euro? A Generalised Purchasing Power Parity Approach, July 2008

2360 Erkki Koskela and Ronnie Schöb, Outsourcing of Unionized Firms and the Impacts of Labour Market Policy Reforms, July 2008

2361 Francisco Alvarez-Cuadrado and Ngo Van Long, A Permanent Income Version of the Relative Income Hypothesis, July 2008

2362 Gabrielle Demange, Robert Fenge and Silke Uebelmesser, Financing Higher Education and Labor Mobility, July 2008

2363 Alessandra Casarico and Alessandro Sommacal, Labor Income Taxation, Human Capital and Growth: The Role of Child Care, August 2008

2364 Antonis Adam, Manthos D. Delis and Pantelis Kammas, Fiscal Decentralization and Public Sector Efficiency: Evidence from OECD Countries, August 2008 
2365 Stefan Voigt, The (Economic) Effects of Lay Participation in Courts - A Cross-Country Analysis, August 2008

2366 Tobias König and Andreas Wagener, (Post-)Materialist Attitudes and the Mix of Capital and Labour Taxation, August 2008

2367 Ximing Wu, Andreas Savvides and Thanasis Stengos, The Global Joint Distribution of Income and Health, August 2008

2368 Alejandro Donado and Klaus Wälde, Trade Unions Go Global!, August 2008

2369 Hans Gersbach and Hans Haller, Exit and Power in General Equilibrium, August 2008

2370 Jan P.A.M. Jacobs and Jan-Egbert Sturm, The Information Content of KOF Indicators on Swiss Current Account Data Revisions, August 2008

2371 Oliver Hülsewig, Johannes Mayr and Timo Wollmershäuser, Forecasting Euro Area Real GDP: Optimal Pooling of Information, August 2008

2372 Tigran Poghosyan and Jakob de Haan, Determinants of Cross-Border Bank Acquisitions in Transition Economies: A Latent Class Analysis, August 2008

2373 David Anthoff and Richard S.J. Tol, On International Equity Weights and National Decision Making on Climate Change, August 2008

2374 Florian Englmaier and Arno Schmöller, Reserve Price Formation in Online Auctions, August 2008

2375 Karl Farmer, Birgit Friedl and Andreas Rainer, Effects of Unilateral Climate Policy on Terms of Trade, Capital Accumulation, and Welfare in a World Economy, August 2008

2376 Monika Bütler, Stefan Staubli and Maria Grazia Zito, The Role of the Annuity’s Value on the Decision (Not) to Annuitize: Evidence from a Large Policy Change, August 2008

2377 Inmaculada Martínez-Zarzoso, The Impact of Urbanization on $\mathrm{CO}_{2}$ Emissions: Evidence from Developing Countries, August 2008

2378 Brian Roberson and Dmitriy Kvasov, The Non-Constant-Sum Colonel Blotto Game, August 2008

2379 Ian Dew-Becker, How Much Sunlight Does it Take to Disinfect a Boardroom? A Short History of Executive Compensation Regulation, August 2008

2380 Cécile Aubert, Oliver Falck and Stephan Heblich, Subsidizing National Champions: An Evolutionary Perspective, August 2008 